Rev. Tomasz Powichrowski

Rev. dcn. Tomasz Mnich Archidiecezjalne Wyższe Seminarium Duchowne w Biatymstoku

\title{
The Sacrament of Holy Orders and the New Metropolitan's Ingress of Archbishop Tadeusz Wojda, SAC into the Cathedral of Białystok
}

The liturgy is the space in which man experiences God's closeness to him in a particularly powerful way. Through the liturgy, God himself becomes palpable to the human senses through gestures, signs, and symbols. In the history of salvation, God, in the person of Jesus Christ, became the clearest sign of the truth about God, who is close to every human being. The history of the Church has not changed for two thousand years. God, who is present in the ministry of concrete people, is close to man and living. Bishops, who participate in the mission and power of Christ the Good Shepherd, have a special mission to watch over the whole flock of Christ and to make God present among His people.

In order to understand the rich power of the symbolism of the person of the bishop, it is necessary to look to the moment of his episcopal ordination. Everything that makes up the rite of consecration is an exposé of the bishop and points to his particular ministry. Since the liturgy is the surest means to sanctify the faithful, it is worthwhile to reflect on the meaning of elements of the rite of the consecration of bishops.

This article examines the theology of the liturgy of episcopal consecration by examining the consecration of His Excellency Archbishop Tadeusz Wojda, SAC, as the Metropolitan of the Archdiocese of Białystok. The liturgy is fruitful insofar as the faithful understand what they experience during it. Therefore, this study will help all who wish to understand the central role of their bishop in the Church, especially this particular servant of God.

Key words: bishop, ordination, Białystok, metropolis, archdiocese. 


\section{Introduction}

The liturgy is a reality that always precedes the one who enters into it. This is because Jesus Christ, our Master and Lord, is the chief Liturgist. Jesus Christ imbues the sacred rites of the Church with his presence, thereby sanctifying them and transfiguring them from purely human activities into something divine. In this way, the liturgy becomes the source and summit of all of the Church's activity. ${ }^{1}$

Each bishop has a special role within the liturgy. By virtue of his ordination, the bishop is the guardian of the liturgical life of the part of Church entrusted to his care. It is the bishop's responsibility to watch over the people to whom Christ has sent him. ${ }^{2}$ In this sense, the bishop "is born" through the liturgical celebration of episcopal ordination. Moreover, as a diocesan bishop, he places on his shoulders part of Christ's concern for the salvation of every human being; in other words, he becomes the good father of the diocesan family.

In light of what is stated above it is worthwhile to consider what takes place during the ordination of a bishop as well as when a bishop takes canonical possession of diocese, since this is what occurred in the Archdiocese of Białystok in 2017. At the Pope Francis request and having reached the age of retirement, Archbishop Edward Ozorowski resigned from his position as the Metropolitan Archbishop of Białystok. Pope Francis appointed Fr. Tadeusz Wojda, SAC, who had been serving as the Undersecretary of the Congregation for the Evangelization of Peoples, as Archbishop Ozorowski's successor. ${ }^{3}$ The Archdiocese of Białystok, therefore, received as its shepherd an experienced theologian with a Franciscan sensitivity to the universality of the Church and the need to proclaim the Gospel always and everywhere. This appointment was providential because, while the Archdiocese of Białystok is only a small part of the Church, it does, nevertheless, contribute to the community of Christians throughout the world

This article considers the canonical norms for a newly ordained bishop, the liturgical norms for the celebration of episcopal ordination, and the canonical norms for taking possession of a diocese. These considerations are marked by rich theological and liturgical symbolism,

\footnotetext{
1 See Paul VI, Constitution on the Sacred Liturgy: Sacrosanctum Concilium (Vatican City, Italy: Libreria Editrice Vaticana, 1963), 10.

2 See The Roman Pontifical: The Rite of Ordination of Bishops, of Priests, and of Deacons. Hereafter abbreviated as RP.

3 See T. Powichrowski, ed., Uroczystość święceń biskupich i ingres do Archikatedry Arcybiskupa Tadeusza Wojdy SAC Metropolity Białostockiego (Bialystok: 2017), 17.
} 
since in order to be effective, a sign, which is also liturgical, must clearly lead to and point out that which it signifies. The liturgy of the Liturgy Church is a treasure of symbols that convey divine realities.

If there are no obstacles, then, in accordance with the norms of the Code of Canon Law (CCL),${ }^{4}$ an appointed bishop should receive the sacrament of episcopal ordination within three months of his nomination. Canon 382 of the CCL states, however, that "one promoted to the office of diocesan bishop must take canonical possession of his diocese within four months [...] if he has not already been consecrated a bishop." This additional month makes it possible for a bishop to prepare well for his consecration and participate in an obligatory retreat.

The nomination of Fr. Tadeusz Wojda, SAC, as bishop of the Archdiocese of Białystok was announced on April 12, 2017..$^{5}$ According to the Code of Canon Law, it was obligatory that he be ordained and take canonical possession of the Archdiocese within four months of that date. After a thorough consideration of all possibilities, the date for of Fr. Tadeusz Wojda's ordination and entrance into the Archcathedral of Białystok was set for Saturday, June 10, 2017.

The ordination of bishops always takes place within the Liturgy of the Eucharist. While the Roman Pontifical: Mass For the Ordination of a Bishop contains the specific and detailed norms for this celebration, ${ }^{6}$ the Polish version of the Caeremoniale Episcoporum, ${ }^{7}$ which was published in 2010, proved particularly helpful in this matter. Specific points of the Caeremoniale Episcoporum provide detailed instructions regarding the celebration of episcopal ordination, ${ }^{8}$ which made it considerably easier to prepare for the event.

A cathedral is the appropriate and privileged place for an episcopal ordination. ${ }^{9}$ For this reason, the Metropolitan Archbishop of Białystok took place in the Archdiocesan Cathedral of the Assumption of the Blessed Virgin Mary. Cardinal Fernando Filoni, Prefect of the Congregation for the Evangelization of Peoples, was the principal consecrator of the ordination. Until his appointment as the Metropolitan of

4 See Code of Canon Law (Vatican City, Italy: Libreria Editrice Vaticana, 1983), can. 379. Hereafter abbreviated as CCL.

5 See T. Powichrowski, Uroczystość święceń biskupich, 18.

6 See $R P, 12-64$.

7 Ceremoniał liturgicznej postugi biskupów (Katowice: Księgarnia Św. Jacka, 2013). Hereafter abbreviated as CLPB.

See $C L P B, 497,500$; for pastoral reasons, bishops can be ordained in another church. 
Białystok, Fr. Tadeusz Wojda, SAC, served as the Undersecretary of the Congregation for the Evangelization of Peoples. The con-celebrants of Fr. Wojda's ordination were the former Archbishop of the Archdiocese of Białystok, Edward Ozorowski, and the Archbishop of WarsawPrague, Henryk Hoser, SAC. ${ }^{10}$ The form of the Mass was chosen from Roman Pontifical, ${ }^{11}$ and the celebrants wore white vestments. Since there were many bishops and priests in attendance from Poland and abroad, the Eucharist was celebrated exclusively in Latin up to the ordination rite.

\section{The Eucharist, the Rite of Episcopal Ordination, and the Rite of Taking Canonical Possession of a Diocese}

For every diocese, priestly ordination at every degree constitutes a particular feast and an opportunity to "return" to the Cenacle where Christ chose to become a "prisoner" at the hands of the priest for all time. This joyful celebration is all the more exalted by the fact that the Church is born anew in its members as it receives new servants of the altar and calls upon the Spirit who enlivens-the same Spirit that animated the thoughts and the will of the apostles-first when they were called, and then when they were sent "into the whole world [to] proclaim the Gospel to every creature" (Mk. 16:15). The ordination of a bishop is a source of joy within each particular church, since its brilliance opens up new sacramental sources. The bishop himself is a visible source of grace and of unity between a particular church and the universal Church; for, bishops are like tiny threads that hold together the entire Catholic Church. ${ }^{12}$ Therefore, the nomination of Fr. Tadeusz Wojda, SAC; his consecration; and his taking canonical possession of the Metropolitan Archdiocese of Białystok that took place on June 10, 2017 were an extraordinary occasion to celebrate.

The solemn celebration of the Eucharist and sacramental Rite of Episcopal Ordination began with a procession from the Archbishop's residence into the archcathedral of Białystok. The archbishop elect, his assistants, and two presbyters processed behind the concelebrating priests and in front of a large crowd of bishops who had come to co-consecrate. According to the prescriptions, ${ }^{13}$ two presbyters, Fr. Krzysztof Wojda, SAC (the bishop's brother) and Fr. Józef Wiśniewski,

10 See T. Powichrowski, Uroczystość święceń biskupich, 18.

$11 \quad$ Cf. $R P, 342$

12 Cf. $R P, 13$.

13 Cf. RP, 17; CLPB, 503. 
assisted the archbishop elect. ${ }^{14}$ After entering the cathedral and approaching and kissing the altar, the bishop elect took his place be- Liturgy tween his two assistants in the presbytery. Cardinal Filoni, who was to preside over the Liturgy of the Word and to confer the Sacrament of Episcopal Ordination, took his place in the cathedral between two co-consecrating bishops..$^{15}$ The order of the Mass up to the Proclamation of the Gospel proceeded in accordance with the liturgical norms stipulated in the Roman Pontifical. ${ }^{16}$ Here it is worth pointing out that the Collect contains a prayer that implores God the grace for the future bishop to faithfully fulfill is service to the Church by trustingly conveying the Word of God, which is the fundamental duty of every bishop, and guiding the People of God.

The rite of ordination began after the Proclamation of the Gospel with the hymn "O Creator Spirit, Come."17 After the congregation finished singing the hymn, the archbishop elect and his two assistants approached the Cardinal Fernando Filoni-the main consecrator-and bowed to the cardinal as a sign of respect. ${ }^{18}$ On behalf of the presbiterium of Białystok, Fr. Józef Wiśniewski asked the cardinal to confer on Fr. Tadeusz Wojda, SAC, the sacrament of episcopal ordination. ${ }^{19}$ In accordance with the Holy See's appointment, the cardinal asked to see the document that confirmed Pope Francis' nomination of Fr. Tadeusz Wojda, SAC, to the office of bishop. After presenting the nomination bull to everyone gathered for the ceremony, Bishop Henryk Ciereszko read the document by which Pope Francis called Fr. Tadeusz Wojda, SAC, to the College of Bishops and conferred on him the dignity of the Metropolitan of Białystok. ${ }^{20}$ This moment in the liturgy of episcopal ordination is very important because it emphasizes the special connection between a bishop and the pope, as well as the pope's freedom to choose whomever he wishes to nominate for the office of bishop. ${ }^{21}$ The Sacrament of Episcopal Ordination cannot be conferred without nominee possessing and presenting the papal bull. Moreover, the proclamation of the papal bull that calls the nominee to the office of

\footnotetext{
14 Cf. T. Powichrowski, Uroczystość święceń biskupich, 23.

$15 \quad$ Cf. $R P$ 29; CLPB, 507-508.

16 Cf. RP, 32; CLPB, 509.

17 Cf. RP, 35; T. Powichrowski, Uroczystość święceń biskupich, 35.

18 Cf. $R P, 37$.

19 Cf. RP, 38; T. Powichrowski, Uroczystość święceń biskupich, 36.

20 See T. Powichrowski, Uroczystość święceń biskupich, 36-38. 
metropolitan is the first necessary step in the archbishop elect's taking canonical possession of the diocese. After the nomination bull was read, Cardinal Filoni gave a homily, during which he encouraged the faithful to love their new bishop and trustingly follow him along the paths of faith.

After the homily ended, the liturgical action moved to the main altar in the Basilica, in front of which the bishop elect stood next to the principal consecrator, Cardinal Filoni. The cardinal then received from the Candidate a promise "to keep the faith and fulfill the office entrusted to him." 22 After receiving the bishop elect's promise and after the proper introduction, ${ }^{23}$ Cardinal Filoni began to sing the Litany of the Saints. This song expresses the Church's belief in the communion of saints and the connection between the Church Militant and the Church Triumphant. ${ }^{24}$ At this moment, the bishop elect lay prostrate with his face on the floor while all other participants in the liturgy knelt for the prescribed amount of time. ${ }^{25}$ Prostration, which is an extreme form of kneeling, expresses humility and the bishop elect's complete offering of self and readiness to serve God. After the Litany of the Saints ended, the cardinal himself rose and pronounced the prayers prescribed in the Roman Pontifical. ${ }^{26}$ This introduction is one of the most important elements of the liturgy and is obligatory for the validity of the ordination. After Cardinal Filoni recited the prayer, everyone, including the archbishop elect, stood.

The main elements of the Rite of Ordination at every degree are the imposition of hands and the prayer of ordination. The archbishop elect subsequently approached Cardinal Filoni and knelt before him. ${ }^{27}$ The cardinal, as the main celebrant and principal consecrator, placed his hands on Fr. Tadeusz Wojda's head. After this, all of the other bishops present did the same. ${ }^{28}$ Laying on of hands is one of the oldest elements of the rite of ordination that can be found in Scripture. It symbolizes the Holy Spirit's assistance, the bestowal of His gifts on the one being ordained, and the transmission of apostolic succession. All bishops

22 CLPB 516; Cf. RP, 40; T. Powichrowski, Uroczystość święceń biskupich, 41-43.

23 Cf. $R P, 41$.

24 Cf. J. Nowak, Komentarze Liturgiczne, (Ząbki: Wydawnictwo APOSTOLICUM, 2007), 28.

$25 \quad$ Cf. $R P, 42 ; C L P B, 517$.

26 Cf. $R P, 43$; T. Powichrowski, Uroczystość święceń biskupich, 45

$27 \quad$ Cf. $R P, 44$.

28 Cf. $R P, 45$. 
present lay their hands on the elect as a sign of the unity of the college of bishops and as a sign of welcome of the ordained into this group. Liturgy According to tradition, this particular moment takes place in absolute prayerful silence.

After all of the bishops present placed their hands on the head of the bishop elect, they gather around the bishop elect in such a way as to not obscure the view of those gathered, so that they can clearly see the liturgy unfold. The two deacons and the Cardinal Filoni approached the bishop elect, who held the Book of the Gospels in his hands. Cardinal Filoni then placed the Book of the Gospels on the Fr. Tadeusz Wojda's head, and the deacons, at that moment, standing on both side of him, held the Book of the Gospels until the cardinal finished praying the prayer of consecration..$^{29}$ Through these liturgical actions, the Church emphasizes that the bishop's service is rooted in the Word and that the Holy Spirit, who penetrates the Word of God, will assist the ordained in all of his future actions and efforts (cf. Lk. 4:18) ${ }^{30}$

The second important moment in the rite of ordination then followed-namely, the prayer of ordination. The main celebrant, Cardinal Filoni, stood without his miter with his hands extended and began the prayer of ordination. ${ }^{31}$ All of the bishops present also extended their hands toward Fr. Wojda and prayed the same prayer in hushed voices. They spoke aloud until it was time to pronounce the words required for the validity of the ordination: "Now, O God, pour upon this elect, the power of the Holy Spirit ... for the everlasting honor and glory of your name." At that point, the principal consecrator, Cardinal Filoni, recited the remainder of the prayer of consecration, and then everyone proclaimed "Amen." 32 After the end of the prayer of consecration, the deacons removed the Book of the Gospels from the head of the newly ordained archbishop, and all of the bishops present received their miters.

At this point in the liturgy, the Explanatory Rites began. These rites involve extremely rich symbols of the bishop's ministry and his mission within the Church. The first symbol is the anointing of newly ordained bishop with the Sign of the Cross with the holy chrism. ${ }^{33}$ The prayer accompanying this action indicates that the fruitfulness of the bishop's episcopal ministry is closely linked with his spiritual

$29 \quad$ Cf. $R P, 46$.

30 Cf. J. Nowak, Komentarze Liturgiczne, 29.

See RP, 47; T. Powichrowski, Uroczystość święceń biskupich, 46-48. 
life. The oil itself recalls the bishop's participation in the grace of the supreme priesthood and his rootedness in the power and mission of Jesus Christ from that moment forward. The oil, which is imposed on the bishop externally, is a spiritual anointing that is meant to penetrate the interior of the new bishop and, thereby, ensure the fruitfulness of his episcopal ministry.

During the second part of the Explanatory Rite, the Cardinal Filoni presented the newly ordained archbishop with the Book of the Gospels. This is a reminder that a bishop's primary duty is to his ministry of the Word "with all patience and skill," ${ }^{34}$ and that he should always seek inspiration within the Gospel in order to deepen his faith.

After Cardinal Filoni presented the Book of the Gospels to the newly ordained Archbishop Wojda, SAC, the cardinal placed the bishop's ring on his finger..$^{35}$ As the prayer accompanying this gesture reveals, the ring is a symbol of the bishop's marriage to the Church, especially the particular church to which he has been called to begin his episcopal ministry. From that moment forward, the bishop should always wear his ring as an expression not only of his dignity as a successor in the office of the Apostles themselves, but also as a sign of his love and fidelity to the Church, the Bride of Christ.

After the ring was placed on the newly ordained bishop's finger, the pallium is traditionally placed on the newly elected bishop. ${ }^{36}$ However, since the Holy Father confers the pallium to new metropolitans in the Vatican on the Feast of Sts. Peter and Paul, and since that feast and event had yet to occur, Archbishop Wojda followed Pope Francis' recommendation and waited to receive the pallium in the Vatican on the Feast of Sts. Peter and Paul.

According to the order of events, the principal consecrator then bestows the miter on the newly ordained minister. The content of the prayer refers to the past brilliance of the symbol of the bishop's headdress. For many centuries, the miter was made of fine materials and decorated with precious stones. When the bishop wore the miter, the stones literally reflected the sun's light, and the bishop became as if the bearer of the brightness of the sun. Since the sun symbolizes the coming of Jesus Christ, the prayer that is recited when the miter is placed on the newly ordained bishop calls the bishop to preserve within himself the brightness of holiness ${ }^{37}$ that he must shine forth

\footnotetext{
$34 \quad R P, 50$; T. Powichrowski, Uroczystość święceń biskupich, 48. 
to the members of his diocese. The two peaks of the miter represent the New and the Old Testaments, recalling once again that there is no Liturgy other way to holiness than through personal adherence to the "Word that became flesh" (see Jn. 1:14).

During the final part of the Explanatory Rites, the principal consecrator gives the newly elected bishop the crozier-the pastoral staff, which is the oldest sign of the bishop's pastoral office and authority. ${ }^{38}$ It is also the most expressive symbol of a bishop's pastoral custody, which, from the moment of his ordination, he must show toward the part of the Church entrusted to him. The prayer that accompanies the giving of the crozier sensitizes the bishop to guard and "watch over all the fold over which the Holy Spirit has established [him] as a bishop." 39 During Archbishop Wojda's ordination, this moment was particularly special for the Archdiocese of Białystok because the crozier that was given to Archbishop Wojda was the same crozier that has been passed down as a legacy through the line of bishops of the Church in Vilniusthe diocese and archdiocese from with the Church in Białystok grew and has drawn its best traditions. ${ }^{40}$ Archbishop Emeritus Edward Ozorowski presented this crozier to the newly elected Archbishop as a sign of the continuity of the episcopal authority that the bishops have shared throughout the years over the Archdiocese of Białystok.

Once the crozier was given to Archbishop Wojda, SAC, an important moment in the ordination of a residential bishop and in the rite of taking canonical possession of a diocese occurred. Cardinal Filoni invited the newly ordained Metropolitan of Bialystok to sit on the cathedra - the bishop's seat-in the archcathedral of the Archdiocese of Białystok. ${ }^{41}$ This symbolic act of taking canonical possession of the archdiocese (by sitting in the seat of authority) signifies that, from that moment on, the new bishop is responsible for directing the liturgical life of the diocese entrusted to him, and ensuring that the deposit of faith is faithfully passed down. After taking possession of the cathedra, Archbishop Tadeusz Wojda, SAC, received a kiss of peace from every bishop present for the celebration. ${ }^{42}$ This kiss was a kind of seal confirming Archbishop Wojda's inclusion in the College of Bishops and a sign of welcome into the circle of the Polish Episcopate. This gesture

Cf. B. Nadolski, Liturgika. Tom I: Liturgika fundamentalna (Poznan: Pallottinum, 2014), 276.

RP, 54; cf. T. Powichrowski, Uroczystość święceń biskupich, 50.

See T. Powichrowski, Uroczystość święceń biskupich, 5-7.

Cf. $R P, 55$.

Cf. $R P, 56$. 
also completed the Rite of Ordination. From this moment forward, the new shepherd of the Archdiocese of Białystok led the celebration of the liturgy. ${ }^{43}$

Since the new metropolitan was already ordained, he sat on the cathedra after the sign of peace. The so-called "homagium" rite then began. According to this rite, the closest associates, including Auxiliary Bishop Henryk Ciereszko, representatives of the clergy, consecrated persons, and the lay faithful all showed signs of honor and respect for the new Metropolitan as he sat on the cathedra. After the homagium, Archbishop Tadeusz Wojda, SAC, invited everyone gathered together to make a profession of faith. The Prayer of the Faithful was omitted because the saints had been implored for their help during the Litany of the Saints. ${ }^{44}$ The remainder of the Liturgy of the Eucharist up to the Prayer after Communion proceeded according to the proper rite. After the Postcommunio, in accordance with the rites contained in the Roman Pontifical, ${ }^{45}$ the song "We Praise You, Lord" was solemnly sung as an expression of gratitude on the part of all those assembled for the gift of the new shepherd of the Archdiocese of Białystok. During the song, the new Metropolitan Archbishop Tadeusz Wojda, SAC, imparted his first pastoral blessing to all of the faithful as he passed through the main nave preceded by two co-consecrators.

Following the blessing, Archbishop Wojda, SAC, signed the relevant documents testifying to his having taken canonical possession of the Archdiocese of Białystok. This act was accompanied by the song Sacerdos et Pontifex, which is a supplication that the new shepherd would intercede before God for his people. After all of the necessary documents were signed, the faithful listened to letters of congratulation sent to Archbishop Wojda, SAC, not only from many parts of Poland, but also from other countries throughout the world. Representatives of the faithful from the Archdiocese of Bialystok also expressed their congratulations and promise to pray for Archbishop Wojda, SAC, and the needs of the archdiocese. Archbishop Jakub, the Ordinary of the Orthodox Diocese of Białystok-Gdansk, spoke to the new archbishop, saying that Białystok was a special place because many Orthodox peoples live there and because it was and continues to be a place where the Gospel has been preached in both Eastern and Western Traditions for many years. Archbishop Jakub also expressed his wish that the

\footnotetext{
$43 \quad$ Cf. $R P, 58 ; C L P B, 528$.

$44 \quad$ Cf. $R P, 58 ; C L P B, 528$.

45 See $R P, 61$.
} 
good spirit of collaboration that has existed between the two fraternal churches (Orthodox and Catholics) would continue.

As the Roman Pontifical stipulated, ${ }^{46}$ Archbishop Tadeusz Wojda, SAC's first pastoral address to the faithful gathered for his ordination and ingress into the archcathedral were the crowing of the kind words and gestures. He shared with everyone present his deep sense of the Holy Spirit's assistance in everything that had taken place. He thanked the ministers for their participation and for transmitting the apostolic succession. He also addressed words of gratitude to all those involved in the preparation of his ordination ceremony. At the end of the formal celebration, Archbishop Tadeusz Wojda, SAC, gave everyone his solemn blessing. ${ }^{47}$ Then, the archbishop, Cardinal Filoni, the bishops, and priests present processed to the sacristy. ${ }^{48}$

Crowds of the faithful gathered in the archcathedral for the ordination of the new Metropolitan of Białystok. Their presence was significant because, by virtue of his ordination, Archbishop Tadeusz Wojda, SAC is the spouse of the Church, particularly the diocese, to whom he has been sent as a safeguard, keeper of the faith, and steward of the holy sacraments. The ordination of a bishop is rich in symbols and signs that emphasize his important role among the People of God. By the power of apostolic succession in this particular part of the Church, "the Apostles' mission to care for the Church constantly continues. This mission must always be carried out through the sacred role of the bishop." ${ }^{49}$ Since it is the bishop's special mission to lead the particular part of the Church entrusted to his care, ${ }^{50}$ it is fitting that the many of the faithful were present at the "birth" of their new shepherd, Archbishop Tadeusz Wojda, SAC. The strong presence of the faithful at his ordination was also reassuring and a source of strength for the new archbishop because it served as a reminder that he was and is not alone under the great pressure of the task that lies ahead of him-that there are many kind and faithful people who accept him with open arms.

\footnotetext{
$46 \quad$ See $R P, 62$.

$47 \quad$ Cf. $R P, 63$.

48 Cf. $R P, 64$.
}

49 Second Vatican Council, Dogmatic Constitution on the Church: Lumen Gentium (Vatican City, Italy: Libreria Editrice Vaticana, 1964), 20. 


\section{Conferring the Pallium}

The ordinary bishops from particular diocesan communities play an important role in the Church. In addition to being responsible for the religious lives of their respective dioceses to which the Holy Father has sent them ${ }^{51}$ bishops are obliged by the Code of Canon Law to fulfill a number of duties as good shepherds of Christ's flock..$^{52}$ A rank exists among dioceses, and some dioceses are given the title of "metropolis." Any bishop of a metropolis is given the title "Archbishop" and has the privilege to wear the pallium.

The pallium is probably the most emblematic of the burden that the diocesan bishop must carry. It is a white sash made of wool and on it are stitched six crosses in black silk. The pallium is made exclusively in Rome and it has a beautiful tradition. Each year, the pope blesses two baby lambs, from which the wool of the pallium comes, on the Feast of St. Agnes the Martyr, January 21. Metropolitan archbishops are allowed to wear the pallium. Within the last year, Pope Francis changed the tradition, and now, each year, newly elected metropolitans receive the pallium from Pope Francis at the Vatican on the Feast of Sts. Peter and Paul, June 29. The day before the palliums are given, Vatican officials place them into a box located in a special alcove in the Confessio of St. Peter's Basilica. The palliums remain there in a niche that is very close to the bones of St. Peter. The pallium signifies the bishop's responsibility to shepherd the flock entrusted to him as well as the communion that exists between the bishops and the Vicar of Christ and the Holy See. ${ }^{53}$ Pope Emeritus Benedict XVI once pointed out that the pallium is meant to symbolize the Good Shepherd's concern for every sheep that He lovingly carries on His shoulders.

Traditionally, on the Feast of Sts. Peter and Paul the Apostles, the pope personally places the pallium on the shoulders of the metropolitan archbishops as an expression their mutual participation in the care of the Church. In order to emphasize the significance of the local church and to provide clearer symbols for the faithful, Pope Francis made a significant change in this area. Since 2015, Pope Francis no longer directly places the pallium on the metropolitan archbishops. Instead, he individually hands them the palliums so that, according to the Pope Francis' wish, the solemn imposition of the pallium can

51 Cf. B. Nadolski, "Biskup," in Leksykon Liturgii (Poznan: Pallottinum, 2006), 162.

$52 \quad$ See CCL, Can. 381-402.

53 Cf. B. Nadolski, Liturgika, 277-281. 
take place at a later date in the respective metropolitan archbishops' respective archdioceses. In this case, the apostolic nuncio places the Liturgy pallium on the shoulders of the archbishops so that the faithful can witness this rite. According to this relatively new norm, Archbishop Tadeusz Wojda, SAC, personally received the pallium from the Holy Father, Pope Francis on June 29, 2017. Then, the ceremonial imposition of pallium by the Apostolic Nuncio, Archbishop Salvatore Pennacchio, took place in the Archdiocese of Białystok on November 5, 2017. ${ }^{54}$

According to the Roman Pontifical, the imposition of the pallium takes place after the placing of the ring and before the giving of the miter during the rite of ordination. ${ }^{55}$ Considering, however, the changes introduced by Pope Francis and in accordance with his design, a separate ceremony for the imposition of the miter was held. In this case, the Caeremoniale Episcoporum determines the method of the imposition of the pallium. ${ }^{56}$ According to the Caeremoniale Episcoporum, the imposition of the pallium takes place within the liturgy of the Eucharist. During the procession into the church, one of the deacons carries the pallium and, "upon reaching the presbyterium, places it on the altar." 57 The bishop who places the pallium on the shoulders of the metropolitan archbishoo presides over the celebration from the cathedral until the imposition of the pallium takes place. ${ }^{58}$ In this case, since Metropolitan Archbishop Tadeusz Wojda, SAC had already taken canonical possession of the Archdiocese of Białystok when he was ordained, his official the appointment by Pope Francis was not read aloud during the rite of imposing the pallium. Instead, after the greeting of the faithful, the rite of the pallium immediately followed. ${ }^{59}$ After approaching the cathedra, the metropolitan kneels before the bishop appointed to place the pallium on his shoulders. ${ }^{60}$ The bishop then takes the pallium from the deacon and, reciting the prayer stipulated in the Caeremoniale Episcoporum, places the pallium

54 See T. M., "Papież Franciszek wręczył paliusz abp. Tadeuszowi Wojdzie," (06.29.2017), http://archibial.pl/wiadomosci/1591-papiez-franciszek-wreczylpaliusz-abp-tadeuszowi-wojdzie/, (Accessed: 09.29.2017).

See $R P, 52$.

56 See CLPB, 1165-1171.

$57 \quad C L P B, 1166$.

$58 \quad$ Cf. CLPB, 1167.

$59 \quad$ Cf. $C L P B, 1168-1169$.

$60 \quad$ Cf. $C L P B, 1169$. 
on the shoulders of the metropolitan archbishop. ${ }^{61}$ This prayer has a deep theological meaning and conveys what the pallium symbolizesnamely, the archdiocese's communion with the Holy See as well as of his pastoral authority among the People of God. For the archbishop himself, the pallium is meant to be a symbol of courage and of putting on the robe of immortality. After the rite concludes, the metropolitan presides over the remainder of the Eucharistic celebration. Instead of the full form of the Penitential Act, only the shorter form, "Lord, have mercy on us," is said. The remainder of the Mass proceeds as usual. ${ }^{62}$

\section{Conclusion}

The diocesan bishop possesses all of the tools necessary to effectively lead the faithful along the paths of faith. For, the bishop is the ordinary steward of all of the sacraments, and the faithful draw from his ministry, as if from the source, the living water of the sacraments. Because the bishop's hands anoint the hands of successive generations of priests, Christ himself becomes present to the People of God through the sign of the cross. At this moment, the words of Christ: "go to the whole world and preach the Gospel to every creature" (see Mk 16:15) are received and joyfully realized in the nave the church. Everything, however, begins at the Last Supper, where Christ instituted the sacramental priesthood. Bishops are the successors of the Apostles, and it is their role to ensure that the will of Christ is continuously carried out in the Church.

Reflecting on the events that take place during the ordination of a bishop and his embrace of a particular community within the Church reveals the significance of his role. Within the Church, the liturgy most clearly conveys theological truths. It is important, however, for the faithful to understand the liturgy so that their participation in these holy rites will be fruitful. For, faith and reason have been and will continue to be like two wings, which lift the faithful to the meaning of the supernatural truths..$^{63}$ There is no greater sign than a shepherd who stands in the power and mission of Christ before the People of God in order to feed the faithful with the Word of God. This is indeed

\footnotetext{
$61 \quad$ Cf. CLPB, 1170.

62 Cf. $C L P B, 1171$.

63 See John Paul II, "Introduction-Know Yourself," Encyclical Letter: Fides et Ratio (Vatican City, Italy: Libreria Editrice Vaticana, 1998).
} 
necessary so that the Gospel can continue to be proclaimed to the ends of the earth. ${ }^{64}$

\section{SAKRAMENT ŚWIĘCEŃ I INGRES DO KATEDRY NOWEGO METROPOLITY BIAŁOSTOCKIEGO KS. ABP. TADEUSZA WOJDY, SAC}

Liturgia to przestrzeń w której szczególnie mocno doświadczamy prawdy o bliskości Boga wobec człowieka. Oto On sam staje uchwytny ludzkim zmysłom za pomocą gestów, znaków i symboli. W historii zbawienia Bóg w osobie Jezusa Chrystusa stał się nam najczytelniejszym znakiem prawdy o Bogu bliskim każdemu człowiekowi. Przez dwa tysiące lat historii Kościoła nic się nie zmieniło. Bóg obecny w posłudze konkretnych ludzi jawi się współczesnemu człowiekowi jako Bóg bliski, Bóg żywy. Szczególną misję w Kościele mają biskupi, którzy uczestnicząc w misji i mocy Chrystusa, Dobrego Pasterza, czuwają nad całą owczarnią Chrystusową i czynią Boga obecnym pośród swojego ludu.

Aby zrozumieć przebogatą moc symboliki skupioną w osobie biskupa trzeba spojrzeć na moment jego święceń w stopniu episkopatu. Wszystko to, co się składa na owe święcenia stanowi swoiste exposé biskupa i wytycza mu konkretną drogę posługiwania. Ponieważ liturgia jest dla wiernych najpewniejszą drogą uświęcenia, warto pochylić się nad znaczeniem tego, co składa się na ryt święceń biskupich.

W niniejszym artykule pochylimy się nad teologią liturgii święceń biskupich, skupiając się na wydarzeniu, które miało miejsce w Archidiecezji Białostockiej, w związku z mianowaniem nowego Metropolity Białostockiego J. E. Abp. Tadeusza Wojdy SAC. Liturgia staje się o tyle owocna, o ile jest przeżywana rozumnie. Toteż niniejsze opracowanie będzie stanowiło konkretną pomoc dla wszystkich, którzy chcą zrozumieć kluczową rolę biskupa w Kościele, szczególnie tym partykularnym.

Słowa kluczowe: biskup, święcenia, archidiecezja, Białystok, metropolia.

\section{Bibliography:}

1. Ceremoniat liturgicznej postugi biskupów. Katowice: Księgarnia Św. Jacka, 2013.

2. Code of Canon Law. Vatican City, Italy: Libreria Editrice Vaticana, 1983.

3. John Paul II. "Introduction-Know Yourself." In Encyclical Letter: Fides et Ratio. Vatican City, Italy: Libreria Editrice Vaticana, 1998.

64 The motto of the new Metropolitan of Białystok is: Oportet praedicari Ewangelium (cf. Mk. 13:10). 
4. M., T. "Papież Franciszek wręczył paliusz abp. Tadeuszowi Wojdzie," (06.29.2017).

5. http://archibial.pl/wiadomosci/1591-papiez-franciszek-wreczyl-paliuszabp-tadeuszowi-wojdzie/. (Accessed: 09.29.2017).

6. Nadolski, B. Leksykon Liturgii. Poznan: Pallottinum, 2006.

7. Nadolski, B. Liturgika. Tom I: Liturgika fundamentalna. Poznan: Pallottinum, 2014.

8. Nowak, J. Komentarze Liturgiczne. Ząbki: Wydawnictwo APOSTOLICUM, 2007.

9. Paul VI, Constitution on the Sacred Liturgy: Sacrosanctum Concilium. Vatican City, Italy: Libreria Editrice Vaticana, 1963.

10. Powichrowski, T., Ed. Uroczystość święceń biskupich i ingres do Archikatedry Arcybiskupa Tadeusza Wojdy SAC Metropolity Białostockiego. Bialystok: 2017.

11. The Roman Pontifical: The Rite of Ordination of Bishops, of Priests, and of Deacons. Totowa: Catholic Book Publishing Corps, 2012.

12. Second Vatican Council, Dogmatic Constitution on the Church: Lumen Gentium. Vatican City, Italy: Libreria Editrice Vaticana, 1964. 